NEWS

\title{
Obama's nuclear-weapons-free vision
}

The 1986 Reykjavik summit between Ronald Reagan and Mikhail Gorbachev marked a turning point in the history of the nuclear-arms race between the two superpowers, with subsequent discussions leading to unprecedented reductions in their nuclear arsenals. The ambitious speech on disarmament that President Barack Obama delivered in Prague on 5 April might be a similar milestone on the way to his stated goal of "a world without nuclear weapons".

"If his administration can achieve half of it we will look back on this as an historic speech," says Jessica Tuchman Mathews, president of the Carnegie Endowment for International Peace in Washington DC. Pavel Podvig, an expert on Russian nuclear affairs at the Center for International Security and Cooperation at Stanford University in California, adds that "it is a great commitment and a very good start, but will very much depend on the specifics of implementation".

The key elements of Obama's speech were arms reductions; ratification of the Comprehensive Nuclear-Test-Ban-Treaty; new powers of international inspection and control over civilian nuclear fuel; controls on the production of weapons-grade materials; new efforts to round up uncontrolled nuclear materials; and new military attitudes. What are the prospects, and obstacles, facing each of these aspirations? - A new Strategic Arms Reduction Treaty (START), to be expanded to include all nuclear-weapons states. The Rekjavik discussions led in 1991 to the signing of the START I treaty, which limited the arsenals of the United States and Russia to 6,000 strategic warheads and 1,600 delivery systems. But this treaty, dramatic at the time, expires in December and its successor treaties were never ratified.

Obama and his Russian counterpart Dmitry Medvedev say they will thrash out a new START treaty by the end of the year; it is reported to involve slimming the arsenals to 1,500 strategic warheads, and later to just 1,000 , while also halving the numbers of missiles and bombers that can deliver them. As to the other acknowledged nuclear powers, the United Kingdom has said this month that it is open to multilateral discussions, but France has made no similar declaration, although it has announced unilateral cuts. China has historically claimed to favour reduction to zero, as long as the United States and Russia act on a similar commitment.

The new bilateral START negotiations will take place against a backdrop of continuing acrimony over US proposals for a missiledefence shield in Europe. "Any discussion with

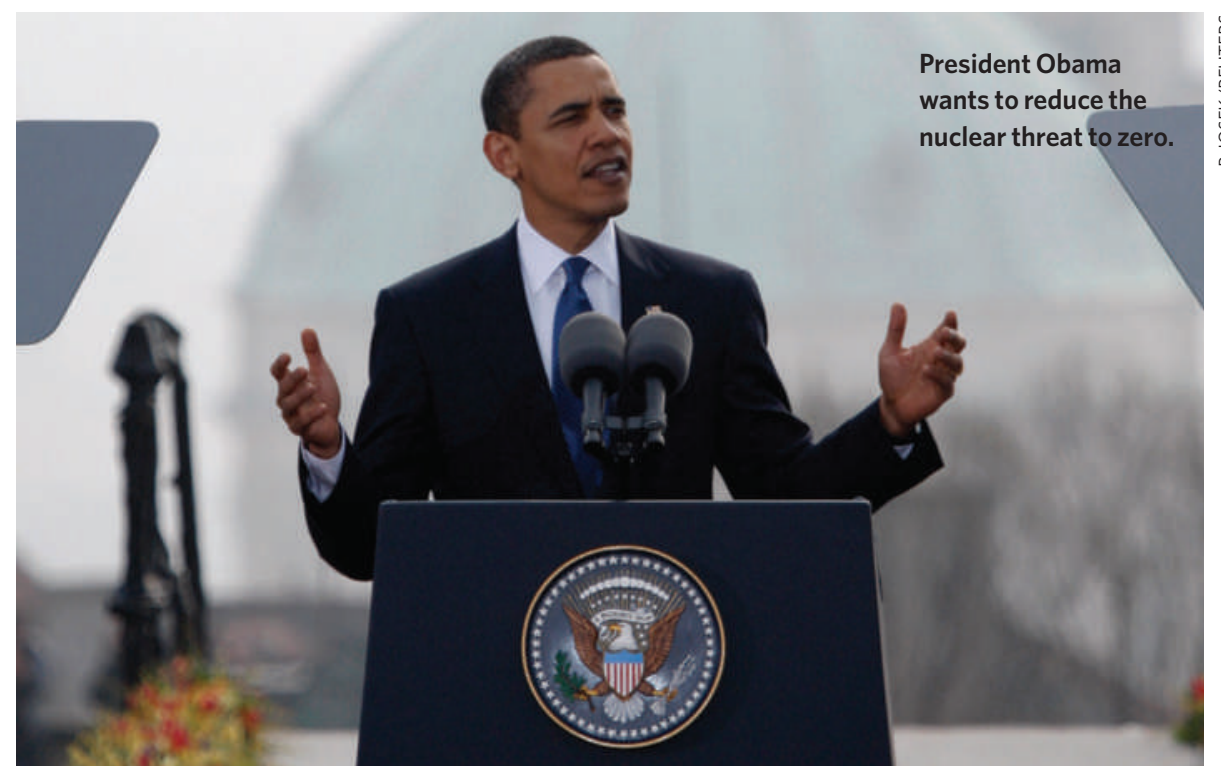

Russia would have to start with a removal of US nuclear weapons from Europe," says Podvig, a move that that would be controversial within NATO. But both the United States and Russia are old hands at the complexities of disarmament deals and, given political will, a treaty along these lines seems quite possible.

- US Ratification of the Comprehensive Nuclear-Test-Ban-Treaty (CTBT). Since it was signed in 1996, 148 states have ratified the CTBT; the United States and China are the only acknowledged nuclear-weapons states not to have done so. The US Senate rejected ratification of the CTBT in 1999, but some technical concerns voiced then have since been alleviated. In terms of verifiability, the worldwide seismic monitoring network has proved able to detect explosions less than a tenth of the size of the Hiroshima blast, and progress has been made in the atmospheric monitoring of 'smoking gun' signatures from noble gases and radionuclides. The 'stockpile stewardship' programme aimed at ensuring the integrity of US weapons without any need for nuclear tests seems so far to have been largely successful.

The US National Academies, which threw their weight behind the CTBT in a 2002 report chaired by John Holdren, now Obama's science adviser, are one of many influential bodies that support US ratification. Prominent US statesmen, including George Shultz and Henry Kissinger, former Republican secretaries of state, have also come out in favour. The Republican voices could be of particular salience to Obama. Although he will need only 8 Republican votes to pass the treaty, compared with the 22 that Bill Clinton needed in 1999, he will probably want a more broadly bipartisan vote in favour.

- More resources and authority to strengthen international inspections. Despite an increasing workload, the budget for the International Atomic Energy Agency (IAEA), which carries out international inspections, has been flat for much of the past two decades. The IAEA's outgoing director-general, Mohamed ElBaradei, says that its US $\$ 400$-million budget should double if the agency is to do its job. Resources are not the only constraint. The IAEA is limited to inspecting declared nuclear facilities, and cannot seek out clandestine sites. A 1997 'additional protocol' to the IAEA's safeguards agreement gives it extra powers in this respect, but many countries - including Iran, where it might have important effects - have yet to sign it.

- A fuel-bank framework for civil cooperation. This proposal gives support to plans by the IAEA to offer countries access to nuclear fuel from facilities that would be put under multilateral control, thus decoupling the use of nuclear power from national enrichment facilities that can also be used for weaponsgrade material - as they have been for example, in North Korea (which tested a satellite launcher/long-range missile on the day of Obama's speech — see page 685).

Such a scheme might help to ease the systemic tension between the IAEA's goals of limiting proliferation and allowing the spread of peaceful nuclear power. The tension was clearly 
visible in the failure of the agency's member states to agree on a successor to ElBaradei last month. Yukiya Amano of Japan was perceived as focused on safeguards whereas Abdul Samad Minty of South Africa was seen as the candidate for extending nuclear power in the developing world. The member states will now put forward new names in the search for a consensus candidate, with a vote likely to be held in May.

- A new treaty to end the production of fissile materials for use in nuclear weapons. A Fissile Material Cut-off Treaty was originally proposed in 1993 by the United Nations General Assembly. It would commit all signatories to stop producing weaponsgrade material. According to Jean du Preez, an arms expert at the Monterey Institute of International Studies in California, this may be a way to cap weapons production in the unofficial weapons states - India, Pakistan, North Korea and Israel — which are currently not members of the 1968 Nuclear Non-Proliferation Treaty (NPT). Such a treaty would pose huge logistical and political challenges in terms of access, inventory and control, but it will be put back on the table at the 2010 NPT review conference, and might in time be a big step towards a nuclear-weapons-free world.

- A new international effort to secure all vulnerable nuclear material. Obama proposed a Global Summit on Nuclear Security, hosted by the United States, with an agenda to include the transformation of two existing programmes - the 2003 Proliferation Security Initiative, an international coalition targeting nuclear trafficking, and the 2006 Global Initiative to Combat Nuclear Terrorism - into permanent international institutions. The IAEA has no clear remit yet in this area.

- Reducing the role of nuclear weapons in US national security strategy. What might seem one of the most mundane disarmament proposals in Obama's speech may be more important even than arms reductions, and may come to underwrite all his non-proliferation proposals. So far, the five nuclear-weapons states recognized by the NPT have largely ignored the treaty's central bargain; that they should disarm just as others refrain from proliferating. Instead, they have maintained, and often extended, the 'crucial' role nuclear weapons have in their policy. By committing to using nuclear weapons only in the event of a nuclear attack, they could go a long way to creating an environment more conducive to broader non-proliferation measures.

Declan Butler

\section{Korean satellite misses orbit}

It was meant to broadcast a booming anthem to leader Kim Jong-il, but if it did it was heard only by sea nymphs ringing its knell. On 5 April, North Korea's third attempt at a satellite launch, like its predecessors, dropped its payload into the Pacific Ocean. Preliminary analyses point to a failure in the rocket's third and final stage, which either did not ignite or did not separate properly from the second stage.

North Korea had hoped to join a growing club of entry-level space-farers. In February, Iran successfully launched a small satellite into low-Earth orbit using the Safir- 2 rocket, and last September, a private company, Space-X of Hawthorne, California, launched a satellite aboard a booster it had designed from scratch, the Falcon 1.

Most observers believe that North Korea's rocket, known as TaepoDong-2, was more primitive than either of these, as it is based on the decades-old Russian and Chinese technology behind the Scud missile. Assuming that heritage, says David

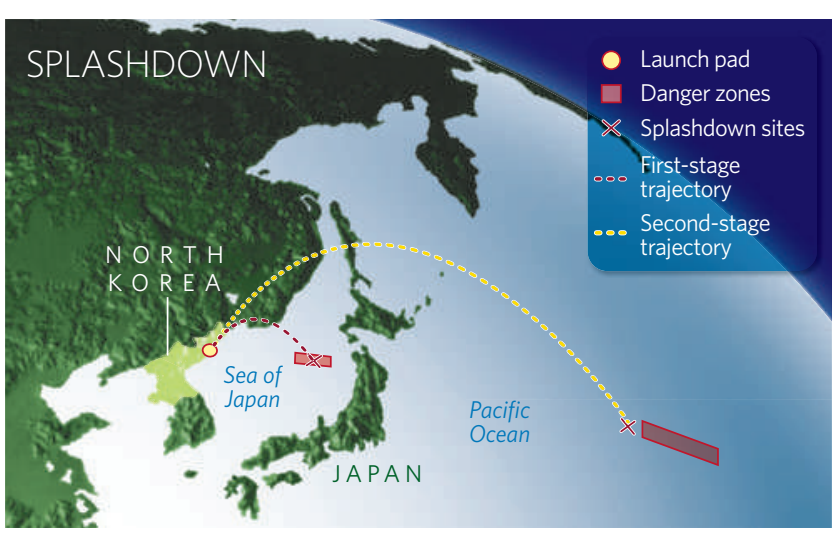
Wright, an arms-control analyst with the Union of Concerned Scientists, a non-profit group based in Cambridge, Massachusetts, the booster would weigh about 80 tonnes, three times the weight of Iran's rocket. Its engines probably used a relatively lowimpulse combination of kerosene fuel and nitric-acid oxidizer, whereas the Falcon uses liquid oxygen.

Those limitations do not mean that such a rocket could not work; it simply didn't work this time. The newest version of the TaepoDong-2 lifted off from the Musudanri launch site at around 2:30 a.m. GMT. Shortly after the launch, the state-run Korean Central News Agency reported that the rocket's payload, a communication satellite, had successfully reached orbit and begun transmitting the "Song of General Kim Jong-il". But a terse statement by the US Northern Command six hours later - by which time any satellite should have circled Earth a few times - said that "no object entered orbit”. Citing diplomatic sources, the South Korean newspaper Chosun Ilbo reported that the rocket's first stage had landed in the Sea of Japan, whereas its remaining stages crashed some 2,700 kilometres farther out in the Pacific (see graphic). The launch's trajectory did not lend itself to the amateur observations from the United States and Europe that often provide corroboration of military launches.

The fact that it got 3,200 kilometres downrange suggests that the first stage of the rocket delivered, according to Wright. That would probably require the synchronized firing of four powerful engines, he says, and "the fact that it worked is a big deal".

A failure between the second and third stages is not uncommon, adds Brian Weeden, a technical consultant with the Secure World Foundation, a non-profit 